\begin{tabular}{|l|l|l|}
\hline \multicolumn{2}{|c|}{ PublisherInfo } \\
\hline \hline PublisherName & $:$ & BioMed Central \\
\hline \hline PublisherLocation & $:$ & London \\
\hline \hline PublisherImprintName & $:$ & BioMed Central \\
\hline \hline
\end{tabular}

\title{
Lytic EBV infection in RA synovial tissue
}

\begin{tabular}{|l|l|l||}
\hline \multicolumn{2}{|c|}{ ArticleInfo } \\
\hline \hline ArticleID & $:$ & 147 \\
\hline \hline ArticleDOI & $:$ & $10.1186 /$ ar-2000-66849 \\
\hline \hline ArticleCitationID & $:$ & 66849 \\
\hline \hline ArticleSequenceNumber & $:$ & 104 \\
\hline \hline ArticleCategory & $:$ & Paper Report \\
\hline \hline ArticleFirstPage & $:$ & 1 \\
\hline \hline ArticleLastPage & $:$ & 4 \\
\hline \hline & & RegistrationDate : 2000-9-27 \\
\hline ArticleHistory & $:$ & OnlineDate \\
\hline \hline ArticleCopyright & $:$ & Current Science Ltd2000-9-27 \\
\hline \hline ArticleGrants & $:$ & \\
\hline \hline ArticleContext & $:$ & 130753311 \\
\hline \hline
\end{tabular}


Aff1 Stanford University Medical Center, Stanford, CA

\section{Keywords}

Antiviral immunity, EBV, lytic infection, RA, viral transmission

\section{Context}

The clinical picture of RA can include abnormalities in antiviral immune responses. EBV is prominent among the list of implicated viruses. EBV infection is highly prevalent among adults and the growth-transforming properties of EBV have been associated with various lymphoproliferative disorders and with nasopharyngeal carcinoma. In RA, levels of serum antibodies to various EBV antigens are elevated, and yet there may be a concomitant drop in T cell immunity to EBV in peripheral blood. These findings suggest an escape of the virus from T-cell surveillance in RA patients, related to either primary RA pathogenesis or iatrogenic immune suppression. Cytotoxic $T$ cells reactive to EBV antigens are commonly found in RA joints, but also in inflamed tissue from non-RA patients. It remains unclear whether recruitment of activated $T$ cells to joints is antigen-specific. EBV DNA has been detected in RA synovial tissue by several groups using PCR; in some cases, EBV reactivation was seen in other arthritides, and other persistent viruses have been found to be activated as well. Little is known about which cell types support viral replication in RA joints.

This work aimed to establish the frequency and abundance of EBV DNA, RNA, and protein in synovial tissue of RA patients and to identify the cells supporting EBV infection or replication in situ.

\section{Significant findings}

Synovial tissue from half of the RA patients, but none of the OA patients, contained detectable EBV DNA; the PCR detection limit was 1 EBV copy per 5000 cells. Lytic infection was most prevalent in younger patients and in those with active lymphocytic infiltrates in their joints. In three patients, EBV DNA levels were high enough to be detectable by Southern blotting of genomic DNA without prior PCR amplification; the maximum copy number observed was 1 EBV copy per 10 cells. In a subset of patients with large amounts of EBV DNA, in situ hybridization detected EBV-encoded small RNA-1 and EBV DNA in infiltrating lymphocytes. Surprisingly, EBV was also detected in synovial lining cells lacking the leukocyte common antigen, CD45. The limited sensitivity of the DNA in situ hybridization suggested that detection of EBV DNA in infected tissue represented lytic infection. Furthermore, 
immunohistochemical analysis revealed several EBV proteins, including lytic-phase proteins, in lymphocytes as well as synovial lining cells. Further evidence for active EBV infection in RA patients was provided by the observation that serum levels of antibodies reactive with EBV antigens were elevated compared to those from OA patients or healthy controls.

\section{Comments}

This report provides evidence for ongoing lytic Epstein-Barr virus (EBV) infection in synovial tissues from a substantial proportion of rheumatoid arthritis (RA) patients. Intriguingly, EBV infection was not confined to infiltrating B lymphocytes but was also found in synovial lining cells. As these cells lack the EBV receptor, CD21, this could reflect cell-to-cell spread from infected B cells. EBV-specific cytotoxic $\mathrm{T}$ lymphocytes seem to be recruited into inflamed tissues in a variety of inflammatory diseases (see Additional information), so EBV reactivation in inflamed tissues might not be unique to RA. Also, given the lack of EBV replication found in some other studies (see Additional information), the generality of these observations for different patient populations remains in doubt.

\section{Methods}

Synovial tissue was obtained from joints of 32 RA and 30 approximately age- and sex-matched osteoarthritis (OA) patients. All RA patients fulfilled 1987 ACR criteria, had well-established disease, and were taking combinations of nonsteroidal anti-inflammatory drugs (NSAIDs), disease modifying antirheumatic drugs (DMARDs), and low-dose prednisolone. DNA from synovial tissue was tested for the level of EBV DNA by semiquantitative PCR and, where high levels of EBV DNA were detected, by Southern blot. To localize EBV-replicating cells in synovial tissue, sections from EBV-DNA-positive patients were further examined for the presence of EBV DNA and EBV-encoded small RNA-1 by in situ hybridization, and frozen sections were examined for the presence of the EBV-encoded proteins BZLF1, gp350/220, and LMP-1 by immunohistochemistry.

\section{Additional information}

Scotet E, Peyrat MA, Saulquin X, Retiere C, Couedel C, Davodeau F, Dulphy N, Toubert A, Bignon JD, Lim A, Vie H, Hallet MM, Liblau R, Weber M, Berthelot JM, Houssaint E, Bonneville M:

Frequent enrichment for $\mathrm{CD8} T$ cells reactive against common herpes viruses in chronic inflammatory lesions: towards a reassessment of the physiopathological significance of $T$ cell clonal expansions found in autoimmune inflammatory processes. Eur J Immunol 1999, 29:973-985 (PubMed abstract). 
Niedobitek G Lisner R Swoboda B Rooney N Fassbender HG Kirchner T Aigner T Herbst H: Lack of evidence for an involvement of Epstein-Barr virus infection of synovial membranes in the pathogenesis of rheumatoid arthritis. Arthritis Rheum 2000, 43:151-154 (PubMed abstract).

\section{References}

1. Takeda T, Mizugaki Y, Matsubara L, Imai S, Koike T, Takada K: Lytic Epstein-Barr virus infection in the synovial tissue of patients with rheumatoid arthritis. Arthritis Rheum. 2000, 43: 1218-1225.

This PDF file was created after publication. 